\title{
Sektor Unggulan Dan Pergeseran Sektoral Kabupaten Gresik 2011-2017 Dalam Perspektif Pembangunan Ekonomi Regional
}

\author{
Abdul Hakim \\ Dosen FEBI UINSA Surabaya | Hakim_ekis@yahoo.co.id
}

\begin{abstract}
Abstrak: Penelitian ini bertujuan Mengetahui sektor unggulan yang dimiliki oleh Dan Pergeseran Sektoral Kabupaten Gresik 201I-2017. Dari hasil analisis LQ, didapatkan bahwa ada tiga sektor unggulan di Kabupaten Gresik yang memberikan kontribusi besar bagi PDRB Gresik dan pertumbuhan sektor lain. Ketiga sektor unggulan tersebut adalah sektor pertambangan dan penggalian, sektor industri pengolahan, sektor pengadaan listrik dan gas. Hasil analisis shift share terhadap seluruh sektor yang ada di Kabupaten Gresik mengalami pertumbuhan yang lebih tinggi dari pada pertumbuhan total seluruh sektor yang ada di Jawa Timur. Kabupaten Gresik memilki sepuluh sektor-sektor maju yaitu (I) Sektor konstruksi, (2) Sektor perdagangan besar dan eceran, (3) Sektor transportasi dan pergudangan, (4) Sektor penyediaan akomodasi dan makan minum, (5) Sektor informasi dan komunikasi, (6) Sektor jasa keuangan dan asuransi, (7) Sektor real estat, (8) Sektor jasa perusahaan, (9) Sektor jasa pendidikan, (10) Sektor jasa kesehatan dan kegiatan sosial. Dalam perspektif ekonomi regional atau wilayah, pengembangan sektor unggulan dan pergerseran sektoral di Kabupaten Gresik memiliki peranan penting dalam mendorong pertumbuhan ekonomi, peningkatan kesempatan kerja, dan penurunan tingkat kemiskinan. Ketiga sektor unggulan yang ada di Kabupaten Gresik (pertambangan dan penggalian, industri pengolahan, sektor pengadaan listrik dan gas) dapat dikembangkan dengan strategi-strategi dalam perencanaan pengembangan wilayah.
\end{abstract}

Keywords : PDRB, LQ. Shift Share, Tipologi Klasen 


\section{Pendahuluan}

Keberhasilan pembangunan ekonomi daerah, sangat ditentukan oleh kebijakan-kebijakan pembangunan yang utamanya bertumpu pada upaya meningkatkan pertumbuhan ekonomi yang mampu menciptakan lapangan kerja secara optimal dari segi jumlah, produktivitas dan efisiensinya. Dalam penentuan kebijakan tersebut, haruslah memperhitungkan kondisi internal maupun perkembangan eksternal. Kondisi internal meliputi wilayah daerah/regionalnya, sedangkan kondisi eksternal meliputi wilayah nasional / internasionalnya. Pemerintah daerah akan bertanggung jawab terhadap segala kebijakan yang diperlukan bagi pembangunan daerahnya, khususnya yang menyangkut pembangunan sarana dan prasarana, investasi dan akses terhadap sumber dana, kebijakan lingkungan, pelayanan dasar (pendidikan dan kesehatan), serta pengembangan sumberdaya manusianya.

Dalam pelaksanaan pembangunan daerah diperlukan perencanaan dan strategi yang tepat karena di setiap daerah mempunyai keadaan yang berbeda, mempunyai karakteristik dan potensi yang bervariasi pula. Penentuan komoditas unggulan nasional dan daerah merupakan langkah awal menuju pembangunan daerah yang berpijak pada konsep efisiensi untuk meraih keunggulan komparatif dan kompetitif dalam menghadapi globalisasi. Langkah menuju efisiensi dapat ditempuh dengan mengembangkan komoditas yang mempunyai keunggulan komparatif baik ditinjau dari sisi penawaran maupun permintaannya. Dari sisi penawaran komoditas unggulan dicirikan oleh superioritas dalam pertumbuhannya pada kondisi fisik, teknologi, maupun kondisi sosial ekonomi di wilayahnya. Sedangkan dari sisi permintaan, komoditas unggulan dicirikan oleh kuatnya permintaan di pasar baik pasar domestik maupun pasar internasional.

Mengetahui sektor unggulan yang dimiliki oleh daerah merupakan kewajiban bagi pemerintah daerah tersebut dalam melakukan perencanaan pembangunan ekonomi daerahnya. Setiap daerah mempunyai sektor-sektor yang bisa dikembangkan. Ada empat syarat agar suatu sektor tertentu menjadi sektor prioritas,

127 OECONOMICUS Journal of Economics 
yakni (1) Sektor tersebut harus menghasilkan produk yang mempunyai permintaan yang cukup besar, sehingga laju pertumbuhan berkembang cepat akibat dari efek permintaan tersebut; (2) Adanya perubahan teknologi yang teradopsi secara kreatif, maka fungsi produksi baru bergeser dengan pengembangan kapasitas yang lebih luas; (3) Harus terjadi peningkatan investasi kembali dari hasil-hasil produksi sektor yang menjadi prioritas tersebut, baik swasta maupun pemerintah; (4) Sektor tersebut harus berkembang, sehingga mampu memberi pengaruh terhadap sektorsektor lainnya.

Setiap daerah memiliki potensi dan keunggulan ekonomi yang menjadi sumber pertumbuhan wilayahnya. Kemampuan memacu pertumbuhan suatu wilayah atau daerah sangat tergantung dari keunggulan atau daya saing sektor-sektor ekonomi di wlayah tersebut. Secara empiris pertumbuhan wilayah dikaitkan dengan adanya proses spesialisasi, interaksi, sentralitas, dan dinamika pola pemukiman. Sehingga pertumbuhan wilayah berlangsung akibat keterkaitan antar daerah yang kuat, di mana salah satu wilayah berfungsi sebagai pusat dan didukung wilayah lainnya sebagai hinterland. Dalam hal ini dapat digarisbawahi bahwa pembangunan wilayah dapat dilakukan melalui pendekatan sektoral maupun kewilayahan.

Dalam perkembangannya suatu daerah juga dapat mengalami perubahan struktur atau pergeseran sektoral. Pergeseran tersebut dapat mengakibatkan perubahan dalam struktur produksi melalui pergeseran kesempatan kerja dan alokasi dana sekaligus memberikan nilai tambah kepada komoditi. Secara umum proses perubahan struktur perekonomian ditandai dengan: (1) Merosotnya pangsa sektor primer (pertanian); (2) Meningkatnya pangsa sektor sekunder (industri);dan (3) Pangsa sektor tersier (jasa) kurang lebih konstan, namun kontribusinya akan meningkat sejalan dengan pertumbuhan ekonomi. Transformasi struktur produksi menunjukkan bahwa sejalan dengan peningkatan pendapatan per kapita, perekonomian suatu negara akan bergeser dari yang semula mengandalkan sektor pertanian mengalami penurunan, saat Gross National Product (GNP)/per kapita meningkat (Kuncoro, 2007). ${ }^{1}$

\footnotetext{
' Kuncoro, Mudrajad. 20I4. Otonomi Daerah Menuju Era Pembangunan Daerah Edisi 3. Penerbit Erlangga: Jakarta
} 
Kabupaten Gresik adalah salah satu kabupaten yang relatif baru yang berada di wilayah Provinsi Jawa Timur. Semula kabupaten ini bernama Kabupaten Surabaya. Kabupaten Gresik merupakan wilayah dataran yang berbatasan dengan pantai. Terletak di sebelah Barat Laut dari Surabaya sebagai Ibukota Provinsi Jawa Timur. Wilayah Kabupaten Gresik merupakan dataran rendah dengan ketinggian 2-12 meter di atas permukaan air laut kecuali Kecamatan Panceng yang mempunyai ketinggian 25 meter di atas permukaan air laut. Hampir sepertiga bagian dari wilayah Kabupaten Gresik merupakan pesisir pantai, yaitu sepanjang Kecamatan Kebomas, sebagian Kecamatan Gresik, Kecamatan Manyar, Kecamatan Bungah dan Kecamatan Ujungpangkah. Sedangkan kecamatan Sangkapura dan Kecamatan Tambak berada di pulau tersendiri yaitu Pulau Bawean.

Dalam perkembangannya Kabupaten Gresik cukup berhasil dalam melakukan pembangunan ekonominya. Kabupaten Gresik termasuk unggul dalam hal pertumbuhan ekonomi dan pesatnya iklim investasi. Pada tahun 2016, pertumbuhan ekonomi di kabupaten Gresik mencapai angka 6,58 persen atau diatas ratarata nasional maupun provinsi. Dari sektor pendapatan domestik regional bruto (PDRB), sampai saat ini angkanya sudah mencapai Rp. 83 triliun pertahun. Tingginya angka PDRB tak lepas dari geliat sektor industri saja yang begitu pesat. Peningkatan pertumbuhan ekonomi di kabupaten Gresik, tentunya berimbas positif pada sektor penghasilan. Dan salah satu indikatornya adalah pendapatan masyarakat di kabupaten sudah mencapai Rp. 107 juta per tahun. Salah satu sektor yang diyakini bisa jadi katalisator adalah pembangunan insfrastruktur sebagai penunjang perkembangan perekonomian di Gresik.

Kondisi Kabupaten Gresik yang berhasil dalam bidang perekonomian tersebut menarik untuk ditelusuri lebih lanjut terkait dengan sektor unggulan yang dimilikinya, pergeseran sektoral yang terjadi, serta kondisinya jika ditinjau dalam perspektif pembangunan ekonomi regional. 


\section{Landasan Teori}

\section{Pertumbuhan Ekonomi}

Proses pertumbuhan ekonomi suatu negara atau daerah dipengaruhi oleh dua factor yaitu faktor ekonomi dan faktor non ekonomi (Adisasmita, 2013:103-106). Faktor ekonomi terdiri dari : 1). Sumber daya alam (SDA). Tersedianya kekayaan sumber daya alam yang tersedia harus dimanfaatkan dan diolah untuk memenuhi kebutuhan hidup masyarakat dan selebihnya dipasarkan keluar wilayah. Sumber daya alam meliputi semua sumber yang tersedia pada alam. 2). Sumber daya manusia. Sumber daya manusia terletak pada tinggi rendahya sekil/keterampilan yang dimiliki manusia. 3). Akumulasi modal. Akumulasi modal atau pembentukan modal adalah peningkatan stok modal dalam jangka waktu tertentu. Pembentukan modal memiliki makna yang penting yaitu masyarakat tidak melakukan kegiatan pada saat ini hanya sekedar untuk memenuhi kebutuhan dan keinginan mengkonsumsi yang mendesak, tetapi juga untuk membuat barang modal, alat-alat perlengkapan, mesin, pabrik sarana angkutan dan lainya. 4). Kemajuan teknologi. Perubahan teknologi dianggap sebagai faktor paling penting dalam proses pertumbuhan ekonomi. Perubahan teknologi telah meningkatkan produktivitas tenaga kerja, modal dan faktor produksi lain.

Sedangkan faktor non ekonomi meliputi seperti organisasi sosial, budaya dan politik. Pembangunan ekonomi berkaitan dengan peran manusia,pandangan masyarakat, kondisi politik dan latar belakang historis halinilah membuat faktor non ekonomi sama pentingnya dengan faktorekonomi. Suatu perekonomian dikatakan mengalami pertumbuhan apabila tingkat kegiatan ekonominya lebih tinggi dari pada apa yang dicapai pada masa sebelumnya. Output akan bertambah atau terjadi pertumbuhan keluaran terutama karena bertambahnya modal dan tenaga kerja yang menghasilkan output tersebut. Di samping itu pertumbuhan output disebabkan oleh adanya peningkatan dalam produktivitas. Pertumbuhan merupakan konsekuensi dari adanya peningkatan produktivitas dan efisiensi dari tenaga kerja dan modal disebut dengan kemajuan teknik.

Pada tingkat daerah, pertumbuhan ekonomi pada dasarnya membahas tentang hal mengapa suatu daerah dapat tumbuh cepat dibandingkan dengan perekonomian pada wilayah yang lebih luas, sedangkan yang lainnya kurang berkembang. Faktor-faktor ekonomi 
apa yang menentukan pertumbuhan ekonomi daerah tersebut. Para ahli mengemukakan bahwa pembangunan ekonomi wilayah tergantung pada sumberdaya yang dimiliki dan permintaan terhadap komoditas yang dihasilkan oleh sumberdaya alamnya. Dalam jangka pendek sumberdaya alam yang dimiliki merupakan aset untuk memproduksi kebutuhan barang dan jasa.

Adam Smith membagi tahapan pertumbuhan ekonomi menjadi lima tahap yang berurutan dimulai dari masa berburu, masa berternak, masa bercocok tanam, masa berdagang, dan tahap masa industri. Menurut teori ini, masyarakat akan bergerak dari masyarakat tradisional kemasyarakat modern yang kapitalis. Dalam prosesnya, pertumbuhan ekonomi akan semakin terpacu dengan adanya sistem pembagian kerja antar pelaku ekonomi. Smith memandang pekerja sebagai salah satu input produksi, pembagian tenaga kerja merupakan titik sentral pembahasan dalam teori ini sebagai upaya peningkatan produktifitas kerja. Dalam pembangunan ekonomi, modal memegang peranan penting. Akumulasi modal akan menentukan cepat atau lambatnya pertumbuhan ekonomi yang terjadi pada suatu negara. Proses pertumbuhan akan terjadi secara simultan dan memiliki hubungan keterkaitan satu sama lainnya. Timbulnya peningkatan kerja pada suatu sektor akan meningkatkan daya tarik bagi pemupukan modal, mendorong kemajuan teknologi, meningkatkan spesialisasi dan memperluas pasar. Hal ini akan mendorong pertumbuhan ekonomi yang semakin cepat.

JJ Rostow dalam bukunya The Stage of Economics Growth (1965) proses pertumbuhan ekonomi bisa dibedakan kedalam lima tahap yaitu: pertama, masyarakat tradisional dimana pada tahapan ini masyarakat menggunakan metode produksi yang masih primitif dengan kebiasaan turun-temurun. Kedua, tahapan prasyarat tinggal landas dimana terjadi transformasi diseluruh sektor kehidupan seperti transformasi dari sektor pertanian menuju sektor perkotaan.Ketiga, tahapan tinggal landas dimana terjadi berbagai perubahan yang drastis baik berbentuk revolusi politik, terciptanya berbagai inovasi dan munculnya pasar-pasar baru. Keempat, tahap menuju kedewasaan dimana industri sudah berkembang dengan pesat, penggunaaan teknologi secara efektif disemua sektor produksi, keahlian tenaga kerja meningkat dan terjadi perubahanperubahan sosial.Kelima, tahap konsumsi tinggi dimana segala

131 OECONOMICUS Journal of Economics 
sesuatu berorientasi pada masalah konsumsi bukan produksi (Zakaria, 2009:113-116). ${ }^{2}$ Teori Harrod-Domar ini dikembangkan oleh Roy F. Harrod (1948) di Inggris dan Evsey D. Domar (1957) di Amerika Serikat. Berbeda dengan Keynes yang melihat perekonomian dalam jangka pendek, teori ini melihat dari sisi jangka panjang yang didasarkan beberapa asumsi: Perekonomian bersifat tertutup. Hasrat menabung $(\mathrm{MPS}=\mathrm{s}$ ) adalah konstan. Proses produksi memiliki koefesien yang tetap. Tingkat pertumbuhan angkatan kerja adalah konstan dan sama dengan tingkat pertumbuhan penduduk. Atas dasar asumsi-asumsi tersebut, Harrod-Domar membuat analisis dan menyimpulkan bahwa pertumbuhan jangka panjang yang mantap (seluruh kenaikan produksi dapat diserap oleh pasar) hanya bisa tercapai apabila terpenuhi syarat-syarat keseimbangan sebagai berikut: $\mathrm{g}=\mathrm{k}=\mathrm{n}$. Di mana: $g$ = Growth (tingkat pertumbuhan output. $\mathrm{k}=$ Capital (tingkat pertumbuhan modal). $\mathrm{n}=$ tingkat pertumbuhan angkatan kerja' Agar terjadi keseimbangan antara tabungan (S) dan investasi (I) harus terdapat kaitan yang saling menyeimbangkan, padahal peran $\mathrm{k}$ untuk menghasilkan tambahan produksi ditentukan oleh $\mathrm{v}$ (rasio modal output). (Tarigan, 2007:49). ${ }^{3}$

Menurut List, dalam bukunya yang berjudul Das Nationale der Politispvhen Oekonomie (1840), sistem liberal yang laizes-faire dapat menjamin alokasi sumber daya secara optimal. Perkembangan ekonomimenurut List melalui 5 tahap yaitu: tahap primitif, beternak, pertanian dan industri pengolahan (Manufacturing), dan akhirnya pertanian, industry pengolahan, dan perdagangan.

Selanjutnya Teori Malthus menitikberatkan perhatian pada perkembangan kesejahteraan suatu negara, yaitu pertumbuhan ekonomi yang dapat dicapai dengan meningkatkan kesejahteraan suatu negara. Kesejahteraan suatu negara sebagian tergantung pada jumlah output yang dihasilkan oleh tenaga kerja dan sebagian lagi pada nilai atas produk tersebut (Jhingan, 1993 dalam Akrom, 2010).

\footnotetext{
2 Zakaria, Junaiddin. "Pengantar Te.ori Ekonomi Makro". Jakarta: Gaung Persada Press. 2009

${ }^{3}$ Tarigan, Robinson. 2012. Ekonomi Regional Teori dan Aplikasi, Bumi Aksara: Jakarta
} 
Dalam teori pertumbuhan ekonomi regional, terdapat beberapa tokoh yang yang tergolong sebagai tokoh teori pertumbuhan neoklasik.Sedangkan faktor non ekonomi meliputi seperti organisasi sosial, budaya dan politik. Pembangunan ekonomi berkaitan dengan peran manusia, pandangan masyarakat, kondisi politik dan latar belakang historis hal inilah membuat faktor non ekonomi sama pentingnya dengan faktor ekonomi. Teori neo klasik sebagai penerus dari teori klasik menganjurkan agar kondisi selalu diarahkan untuk menuju pasar sempurna.Dalam keadaan pasar sempurna perekonomian bisa tumbuh maksimal.Analisis lanjutan dari paham neo klasik menunjukkan bahwa terciptanya suatu pertumbuhan yang mantap (steady growth), diperlukan suatu tingkat $\mathrm{s}$ (saving) yang pas dan seluruh keuntungan pengusaha diinvestasikan kembali di wilayah itu.

Dalam ekonomi model ekonomi klasik, kebijakan yang perlu ditempuh adalah meniadakan hambatan dalam perdagangan termasuk perpindahan orang, barang dan modal.Harus dijamin kelancaran arus barang, modal, tenaga kerja dan dan perlunya penyebarluasan informasi pasar.Harus diusahakannya terciptanya prasarana perhubungan yang baik dan terjaminnya keamanan, ketertiban, dan kestabilan politik (Tarigan, 2005). Selain itu dalam teori pertumbuhan neo klasik terdapat teori pertumbuhan jalur cepat. Teori Pertumbuhan Jalur Cepat (Turnpike) diperkenalkan oleh Samuelson (2001). Setiap negara/wilayah perlu melihat sektor/komoditi apa yang memiliki potensi besar dan dapat dikembangkan dengan cepat, baik karena potensi alam maupun karena sektor itu memiliki competitive advantage untuk dikembangkan. Artinya dengan kebutuhan modal yang sama sektor tersebut dapat memberikan nilai tambah yang lebih besar, dapat berproduksi dalam waktu relatif singkat dan volume sumbangan untuk perekonomian yang cukup besar. Agar pasarnya terjamin, produk tersebut harus dapat menembus dan mampu bersaing pada pasar yang lebih luas.

Perkembangan struktur tersebut akan mendorong sektor lain untuk turut berkembang sehingga perekonomian secara keseluruhan akan tumbuh. Mensinergikan sektor-sektor adalah membuat sektor sektor saling terkait dan saling mendukung sehingga pertumbuhan sektor yang satu mendorong pertumbuhan

133 OECONOMICUS Journal of Economics 
sektor yang lain, begitu juga sebaliknya. Menggabungkan kebijakan jalur cepat dan mensinergikannya dengan sektor lain yang terkait akan mampu membuat perekonomian tumbuh cepat.

\section{Produk Domestik Regional Bruto (PDRB)}

Produk Domestik Regional Bruto (PDRB) merupakan nilai tambah bruto seluruh barang dan jasa yang tercipta atau dihasilkan di wilayah domestik suatu negara yang timbul akibat berbagai aktivitas ekonomi dalam suatu periode tertentu tanpa memperhatikan apakah faktor produksi yang dimiliki residen atau non-residen. Penyusunan PDRB dapat dilakukan melalui 3 (tiga) pendekatan yaitu pendekatan produksi, pengeluaran, dan pendapatan yang disajikan atas dasar harga berlaku dan harga konstan (riil). PDRB atas dasar harga berlaku atau dikenal dengan PDRB nominal disusun berdasarkan harga yang berlaku pada periode penghitungan, dan bertujuan untuk melihat struktur perekonomian. Sedangkan PDRB atas dasar harga konstan (riil) disusun berdasarkan harga pada tahun dasar dan bertujuan untuk mengukur pertumbuhan ekonomi.

Menurut pendekatan produksi PDRB adalah jumlah nilai tambah atas dasar harga dasar atas barang dan jasa yang dihasilkan oleh berbagai unit produksi di wilayah suatu wilayah dalam jangka waktu tertentu (biasanya satu tahun) ditambah pajak atas produk neto (pajak kurang subisidi atas produk). Unit-unit produksi tersebut dalam penyajian ini dikelompokkan menjadi 17 kategori lapangan usaha yaitu: (A) Pertanian, Kehutanan, dan Perikanan, (B) Pertambangan dan Penggalian, (C) Industri Pengolahan, (D) Pengadaan Listrik dan Gas, (E) Pengadaan Air, Pengelolaan Sampah, Limbah dan Daur Ulang, (F) Konstruksi, (G) Perdagangan Besar dan Eceran; Reparasi Mobil dan Sepeda Motor, $(\mathrm{H})$ Transportasi dan Pergudangan, (I) Penyediaan Akomodasi dan Makan Minum, (J) Informasi dan Komunikasi, (K) Jasa Keuangan dan Asuransi, (L) Real Estat, (M,N) Jasa Perusahaan, (O) Administrasi Pemerintahan; Pertahanan dan Jaminan Sosial Wajib, (P) Jasa Pendidikan, (Q) Jasa Kesehatan dan Kegiatan Sosial, dan $(\mathrm{R}, \mathrm{S}, \mathrm{T}, \mathrm{U})$ Jasa lainnya. Setiap kategori tersebut dirinci lagi menjadi subkategori. 
Menurut pendekatan Pendapatan PDRB merupakan jumlah balas jasa yang diterima oleh faktor-faktor produksi yang ikut serta dalam proses produksi di suatu wilayah dalam jangka waktu tertentu (biasanya satu tahun). PDRB merupakan penjumlahan kompensasi pekerja, surplus usaha bruto, pendapatan campuran bruto, dan pajak kurang subsidi atas produksi dan impor.

Sedangkan PDRB dalam pendekatan Pengeluaran adalah semua komponen permintaan akhir yang terdiri dari: (1) Pengeluaran Konsumsi Rumah Tangga, (2) Pengeluaran Konsumsi Lembaga Non Profit Rumah Tangga/LNPRT, (3) Pengeluaran Konsumsi Pemerintah, (4) Pembentukan Modal Tetap Domestik Bruto, (5) Perubahan Inventori, dan (6) Ekspor Neto (ekspor dikurangi impor). Secara konsep ketiga pendekatan tersebut akan menghasilkan angka yang sama. Jadi, jumlah pengeluaran akan sama dengan jumlah barang dan jasa akhir yang dihasilkan dan harus sama pula dengan jumlah pendapatan untuk faktor-faktor produksi. PDRB yang dihasilkan dengan cara ini disebut sebagai PDRB atas dasar harga pasar. PDRB maupun agregat turunannya disajikan dalam dua versi penilaian, yaitu atas dasar harga berlaku dan atas dasar harga konstan. Disebut sebagai harga berlaku karena seluruh agregat dinilai dengan menggunakan harga pada tahun berjalan, sedangkan harga konstan penilaiannya didasarkan kepada harga satu tahun dasar tertentu. PDRB selalu dijadikan dasar utama dalam menentukan tingkat perekonomian suatu daerah sekaligus perbandingannya dengan daerah-daerah lain. PDRB menjadi indikator makro yang selalu diperhatikan dalam setiap periode perekonomian. Location Quotient (LQ), Dinamic Location Quotient (DLQ), dan Shift Share (SS).

Analisis Location Quotient (LQ) merupakan analisis yang paling populer digunakan untuk mengetahui sektor unggulan dan non unggulan di suatu wilayah. Nilai LQ dipakai untuk petunjuk dasar dari penentuan sektor yang berpotensi untuk dikembangkan di suatu daerah. Seperti yang telah diketahui bahwa sektor unggulan adalah sektor yang memiliki nilai $L Q>1$, sedangkan sektor non unggulan adalah sektor yang mempunyai nilai $L Q<1$. 
Cara perhitungan LQ dan dengan perhitungan DLQ sebagai berikut:

$$
\mathrm{LQ}_{\mathrm{i}}=\frac{E \mathrm{ij} / \mathrm{Ei}}{\operatorname{Ein} / E n}
$$

Dimana:

$\mathrm{LQ}=$ Koefisien Location Quotient

Eij = PDRB sektor i di wilayah Kabupaten Gresik

$\mathrm{Ej}=$ Total PDRB sektor $\mathrm{i}$ di wilayah Provinsi Jawa Timur

En $=$ Total PDRB di wilayah referensi

Untuk mengeliminir kelemahan dari metode Location Quotient (LQ) maka menurut Saharuddi dalam Aprialis (2011) dapat dikembangkan Dinamic Location Quotient (DLQ). Dengan metode ini faktor waktu mempunyai pengaruh. Dengan berjalannya waktu sektor yang semula merupakan sektor basis dan non basis akan dapat diketahui apakah akan tetap atau mengalami reposisi dalam kurun waktu tertentu. Dinamic Location Quotient (DLQ) prinsipnya sama dengan (LQ), hanya mengintroduksikan laju pertumbuhan digunakan asumsi bahwa setiap nilai tambah sektor maupun PDRB mempunyai rata-rata laju pertumbuhan per tahun sendiri-sendiri selama kurun waktu (0) dan tahun (t). Tafsiran terhadap DLQ pada dasarnya sama dengan LQ kecuali perbandingan ini lebih menekankan laju pertumbuhan. Adapun rumus yang digunakan adalah:

$$
\mathrm{DLQ}=\left[\frac{(1+g i n) /(1+g n)}{(1+g t) /(1+g)}\right] \mathrm{t}
$$

Di mana :

DLQ = Koefisien Dynamic Location Quotient

gin = laju pertumbuhan sektor i di wilayah studi

gn = total laju pertumbuhan PDRB di wilayah studi

gt = laju pertumbuhan sektor i di wilayah referensi

$\mathrm{g}=$ total laju pertumbuhan PDRB di wilayah referensi

kriteria :

a. DLQ > 1, berarti proporsi laju pertumbuhan sektor i terhadap laju pertumbuhan PDRB Kabupaten lebih cepat dibandingkan laju pertumbuhan sektor tersebut terhadap PDRB Provinsi, masih dapat diharapkan untuk terus menjadi basis di masa yang akan datang; 
b. $\mathrm{DLQ}=1$, berarti laju pertumbuhan sektor i terhadap laju pertumbuhan PDRB kabupaten sebanding dengan laju pertumbuhan sektor tersebut terhadap PDRB Provinsinya.

c. DLQ < 1, berarti proporsi laju pertumbuhan sektor i terhadap laju pertumbuhan PDRB Kabupaten lebih rendah dibandingkan laju pertumbuhan sektor tersebut terhadap PDRB Provinsi. Masa depan sektor ini akan kalah bersaing dengan sektor yang sama dengan sektor Provinsi, sektor i tidak dapat diharapkan untuk menjadi basis di masa yang akan datang.

Sedangkan teknik analisis data yang berkaitan dengan pergeseran sektoral adalah dengan menggunakan teknik Analisis Shift Share. Pada prinsipnya Shift Share Analysis berusaha untuk memecah atau mendekomposisi besaran deviasi (selisih) antara nilai tambah (menggunakan pendekatan nilai tambah) pada tahun ke-t dengan nilai tambah pada tahun dasar, dan biasanya dinotasikan $\Delta Y$ i. Terdapat tiga variabel dekomposisi yang menjadi komponen dari deviasi $\Delta Y \mathrm{Y}$, yaitu komponen pertumbuhan regional (PR), komponen pertumbuhan proporsional (PP), dan komponen pertumbuhan pangsa wilayah (PPW). Jika dituangkan dalam bentuk persamaan matematik menjadi :

$$
\Delta Y i=P R i j+P P i j+P P W i j
$$

Atau secara rinci dapat dinyatakan :

$$
\Delta Y^{\prime} i j-Y i j=\Delta Y i j=Y i j(R a-1)+Y i j(R i-R a)+Y i j(r i-R i)
$$

Analisis shift share (SS) berguna untuk mengidentifikasi sumber pertumbuhan ekonomi baik dari sisi pendapatan maupun dari sisi tenaga kerja pada suatu wilayah tertentu. Melalui analisis shift share dapat dianalisis besarnya sumbangan pertumbuhan dari tenaga kerja dan pendapatan masing-masing sektor di wilayah tertentu. Penggunaan analisis ini sangat bermanfaat bagi pemerintah daerah untuk mengetahui besarnya tingkat pertumbuhan ekonomi di suatu wilayah yang bersangkutan. Keunggulan utama dari analisis shift share adalah dapat melihat perkembangan produksi atau kesempatan kerja di suatu wilayah serta melihat pertumbuhan sector-sektor perekonomian suatu wilayah selama dua periode waktu.

Analisis shift share mempunyai banyak kegunaan, di antaranya adalah untuk melihat hal- hal berikut:

1. Perkembangan sektor perekonomian di suatu wilayah OECONOMICUS Journal of Economics 
terhadap perkembangan ekonomi wilayah yang lebih luas.

2. Perkembangan sector-sektor perekonomian jika dibandingkan secara relatif dengan sector-sektor lainnya.

3. Perkembangan suatu wilayah dibandingakan dengan wilayah lainnya sehingga dapat membandingkan besarnya aktivitas suatu sektor pada wilayah tertentu dan pertumbuhan antar wilayah.

4. Perbandingan laju sector-sektor perekonomian di suatu wilayah dengan laju pertumbuhan perekonomian nasional serta sector-sektornya.

\section{Pembangunan Ekonomi Regional}

Pembangunan ekonomi adalah serangkaian usaha dan kebiksanaan yang bertujuan untuk meningkatkan taraf hidup masyarakat, memperluas lapangan pekerjaan, memeratakan pembagian pendapatan masyarakat, meningkatkan hubungan ekonomi regional dan mengusahakan pergeseran kegiatan ekonomi dari sektor primer ke sektor sekunder dan tersier. Dengan kata lain pembangunan ekonomi adalah mengusahakan agar pendapatan masyarakat naik secara mantap dan dengan tingkat pemerataan sebaik mungkin.

Pembangunan ekonomi daerah adalah suatu proses pemerintah daerah dan masyarakat dalam mengelola sumberdaya-sumberdaya yang ada dan membentuk suatu pola kemitraan antara pemerintah daerah dengan sektor swasta untuk menciptakan suatu lapangan kerja baru dan merangsang perkembangan kegiatan ekonomi (pertumbuhan ekonomi) dalam wilayah tersebut. Masalah pokok dalam pembangunan daerah adalah terletak pada penekanan terhadap kebijakan-kebijakan pembangunan yang didasarkan pada kekhasan daerah yang bersangkutan dengan menggunakan potensi sumberdaya manusia, kelembagaan dan sumber daya fisik secara local (daerah). Orientasi ini mengarah kita kepada pengambilan inisiatif-inisiatif yang berasal dari daerah tersebut dalam proses pembangunan untuk menciptakan kesempatan kerja baru dan merangsang peningkatan kegiatan ekonomi.

Setiap upaya pembangunan daerah mempunyai tujuan utama untuk meningkatkan jumlah dan jenis peluang kerja untuk masyarakatnya. Dalam upaya pencapaian tujuan tersebut, pemerintah daerah bersama masyarakatnya harus secara bersama- 
sama mengambil inisiatif pembangunan daerah. Pemerintah daerah mampu menaksir potensi sumber daya yang diperlukan untuk merangsang dan membangun perekonomian daerah.

Beberapa teori dalam pembangunan ekonomi regional antara lain 1). Teori Basis Ekonomi (Economic Base Theory)

Teori basis ekonomi ini menyatakan bahwa faktor penentu utama pertumbuhan ekonomi suatu daerah adalah berhubungan langsung dengan permintaan barang dan jasa dari luar daerah (Arsyad, 2002:116). ${ }^{4}$ Teori basis ini digolongkan ke dalam dua sektor yaitu sektor basis dan sektor non basis. Sektor basis merupakan sektor yang melakukan aktifitas berorientasi ekspor keluar batas wilayah perekonomian yang bersangkutan. Sektor basis memiliki peran penggerak utama (primer mover) dalam pertumbuhan suatu wilayah. Semakin besar ekspor suatu wilayah semakin maju pertumbuhan wilayah. Setiap perubahan yang terjadi pada sektor basis menimbulkan efek ganda dalam perekonomian regional. Sedangkan sektor non basis adalah sektor yang menyediakan barang dan jasa untuk masyarakat di dalam batas wilayah perekonomian bersangkutan.Luas lingkup produksi dan pemasaran bersifat lokal.Inti dari teori ini adalah bahwa arah dan pertumbuhan suatu wilayah ditentukan oleh ekspor wilayah tersebut.

Strategi pembangunan daerah yang muncul berdasarkan teori ini adalah penekanan terhadap arti penting bantuan kepada dunia usaha yang mempunyai pasar secara nasional maupun internasional. Implementasi kebijakannya mencakup pengurangan hambatan/batasan terhadap perusahaan-perusahaan yang berorientasi ekspor yang ada dan akan didirikan di daerah tersebut.

2). Teori Tempat Sentral

Teori tempat sentral (central place theory) menganggap bahwa ada hirarki tempat (hierarchy of places). Setiap tempat sentral didukung oleh sejumlah tempat yang lebih kecil yang menyediakan sumberdaya (industri dan bahan baku). Tempat sentral tersebut merupakan suatu pemukiman yang menyediakan jasa-jasa bagi penduduk daerah yang mendukungnya.

${ }^{4}$ Arsyad, Lincolin. "Pengantar Perencanaan Ekonomi Daerah (edisi kedua)".Yogyakarta: BPFE. 2002 


\section{3). Teori Kausasi Kumulatif}

Kondisi daerah-daerah sekitar kota yang semakin buruk menunjukkan konsep dasar dari tesis kausasi kumulatif (cumulative causation) ini. Kekuatan-kekuatan pasar cenderng memperpanjang kesenjangan antara daerah-daerah tersebut.Maka dari itu kita mengenal ada yang disebut daerah maju dan daerah terbelakang.Daerah maju mengalami akumulasi keunggulan kompetitif dibanding daerah-daerah lainnya. Inilah yang disebut sebagai backwash effect (Mrydal, 1957 dalam Arsyad, 2002). ${ }^{5}$ Menurut model ini, ketimpangan pembangunan regional hanya akan dapat dikurangi melalui program pemerintah. Apabila hanyadiserahkan pada mekanisme pasar, maka ketimpangan regional akan terus meningkat seiring dengan peningkatan pembangunan (Sjafrizal, 2008:98). ${ }^{6}$

4). Model Daya Tarik (Attraction)

Teori daya tarik industri adalah model pembangunan ekonomi yang paling banyak digunakan oleh masyarakat.Teori ekonomi yang mendasarinya adalah bahwa suatu masyarakat dapat memperbaiki posisi pasarnya terhadap industrialis melaui pemberian subsidi dan insentif (Arsyad, 2002:118). ${ }^{7}$

5). Teori Ekonomi Neo Klasik

Menurut teori ini ada 2 konsep pokok dalam pembangunan ekonomi daerah yaitu keseimbangan (equilibrium) dan mobilitas faktor produksi daerah. Artinya, sistem perekonomian akan mencapai keseimbangan alamiahnya jika modal bias mengalir tanpa retriksi (pembatasan). Oleh karena itu, modal akan mengalir dari daerah yang ber upah tinggi menuju daerah yang ber upah rendah(Arsyad, 2004: 300). ${ }^{8}$

\footnotetext{
${ }^{5}$ Arsyad, Lincolin. "Pengantar Perencanaan Ekonomi Daerah (edisi kedua)". Yogyakarta: BPFE. 2002

${ }^{6}$ Sjafrizal, 2008. Ekonomi Regional, Teori dan Aplikasi, Baduose Media, Cetakan Pertama, Padang.

${ }^{7}$ Arsyad, Lincolin. "Pengantar Perencanaan Ekonomi Daerah (edisi kedua)". Yogyakarta: BPFE. 2002

${ }^{8}$ Arsyad, Lincolin, 2004. Ekonomi Pembangunan. Yogyakarta: STIE YKPN.
} 
Hal penting lain dalam pembangunan ekonomi regional adalah Perencanaan Dalam Pembangunan Ekonomi Daerah. Perencanaan adalah suatu proses untuk mencapai tujuan. Perencanaan dalam arti luas adalah suatu proses mempersiapkan secara sistematis kegiatankegiatan yang akan dilakukan untuk mencapai suatu tujuan tertentu, perencanaan merupakan suatu cara bagaimana mencapai tujuan sebaik-baiknya (maximum output) dengan sumber-sumber yang ada supaya lebih efisien dan efektif. Sedangkan perencanaan pembangunan adalah suatu proses perubahan multidimensi kearah yang lebih baik dengan pengarahan penggunaan sumberdayasumberdaya ekonomi yang terbatas adanya, untuk mencapai tujuantujuan keadaan sosial ekonomi yang lebih baik secara lebih efisien dan efektif.

Menurut Friedman dalam Tarigan (2005:04) perencanaan adalah cara berfikir untuk mengatasi permasalahan sosial dan ekonomi, untuk menghasilkan sesuatu dimasa depan. Disini Friedman menentukan sasaran yang dituju yaitu keinginan kolektif dan mengusahakan keterpaduan dalam kebijakan dan program. ${ }^{9}$ Menurut Arsyad (2010:157) perencanaan adalah Suatu Proses yang berkesinambungan yang mencakup keputusan-keputusan atau pilihanpilihan berbagai alternatif pembangunan sumber daya untuk mencapai tujuan-tujuan tertentu pada masa yang akan datang. Berdasarkan defenisi tersebut menurut Arsyad terdapat empat elemen dasar perencanaan yaitu :

1) Perencanaan berarti memilih. Yang dapat diartikan bahwa tahap perencanaan ini adalah proses pemilihan sumberdayasumberdaya yang akan digunakan dalam mewujudkan tujuan yang diiginkan.

2) Perencanaan merupakan alat pengalokasian sumberdaya. Dengan kata lain dalam tahapan perencanaan ini dilakukan suatu proses alokasi besarnya sumberdaya-sumberdaya yang digunakan dalam perwujutan tujuan yang diiginkan.

3) Perencanaan merupakan alat untuk mencapai tujuan. Tujuan ini tercermin dari target atau ukuran kinerja yang dicapai.

\footnotetext{
${ }^{9}$ Tarigan, Robinson. "Perencanaan Pembangunan Wilayah (edisi revisi)". Jakarta:
}

Bumi Aksara. 2005 
4) Perencanaan untuk masa depan. Dapat diartikan bahwa perencanaan merupakan tahap yang diperlukan untuk masa depan. ${ }^{10}$

Perencanaan ekonomi daerah bukanlah perencanaan dari suatu daerah, melainkan perencanaan untuk satu daerah. Perencanaan suatu daerah dapat dilihat secara keseluruhan merupakan suatu unit ekonomi (economicentity) yang didalamnya terdapat beberapa unsur yang berinteraksi satudengan yang lain (Kuncoro, 2012:03). Ada tiga unsur dasar dari perencanaanpembangunan ekonomi daerah jika dikaitkan dengan hubungan pusat dandaerah yaitu :

1. Perencanaan pembangunan ekonomi daerah yang realistis memerlukan pemahaman tentang hubungan antara daerah dengan lingkungan nasional dimana daerah tersebut merupakan bagian darinya, keterkaiatan secara mendasar antara keduanya, dan konsekuensi akhir dari interaksi tersebut.

2. Sesuatu yang tampak baik bagi secara nasional belum tentu baik untuk daerah. Sebaliknya yang baik bagi daerah belum tentu baik untuk nasional.

3. Perangkat kelembagaan yang tersedia untuk pembangunan daerah. Misalnya administrasi, proses penggambilan putusan dan oteritas biasanya sangat berbeda pada tingkat daerah dengan yang tersedia pada tingkat pusat.

Adapun menurut Blakely dalam Kuncoro (2012:53) ada enam tahapan dalam peroses perencanaan pembangunan ekonomi daerah yaitu : 1. Pengumpulan data dan analisis data, 2. Pemilihan strategi pembangunan daerah, 3. Pemilihan proyek-proyek pembangunan, 3 . Pembuatan rencana tindakan, 5. Penentuan perincian proyek dan 6. Persiapan perencanaan secara keseluruhan dan implementasi. ${ }^{11}$

\footnotetext{
${ }^{10}$ Arsyad, L. 1999. Pengantar Perencanaan dan Pembangunan Ekonomi Daerah (I ${ }^{\text {st }}$ d.). Yogyakarta: BPFE.

I' Kuncoro, Mudrajad. 2014. Otonomi Daerah Menuju Era Pembangunan Daerah Edisi 3. Penerbit Erlangga: Jakarta.
} 


\section{Sektor Unggulan Kabupaten Gresik 2011-2017}

Hasil dari perhitungan LQ Kabupaten Gresik pada tahun 20112017. menjelaskan bahwa sektor ekonomi yang tergolong sebagai sektor unggulan di Kabupaten Gresik dengan nilai LQ lebih dari 1 ada tiga sektor yaitu sektor pertambangan dan penggalian dengan nilai LQ $(2,19)$, sektor industri pengolahan dengan nilai LQ $(1,65)$, sektor pengadaan listrik dan gas dengan nilai LQ $(1,63)$. Ketiga sektor ini merupakan sektor yang memiliki kontribusi besar dalam PDRB Kabupaten Gresik, dan laju ketiga sektor ini lebih tinggi dari pada sektor lain.

Ketiga sektor unggulan tersebut memiliki kemampuan ekspor (basis) kepada daerah lain sehingga memberikan keuntungan lebih bagi Kabupaten Gresik. Bukan hanya memiliki kemampuan ekspor (basis), ketiga sektor ini bisa juga menjadi pendorong bagi pertumbuhan sektor-sektor lain.

Hasil Perhitungan LQ Kabupaten Gresik

\begin{tabular}{|c|l|c|c|c|c|c|c|c|c|}
\hline No & \multicolumn{1}{|c|}{ Sektor } & $\mathbf{2 0 1 1}$ & $\mathbf{2 0 1 2}$ & $\mathbf{2 0 1 3}$ & $\mathbf{2 0 1 4}$ & $\mathbf{2 0 1 5}$ & $\mathbf{2 0 1 6}$ & $\mathbf{2 0 1 7}$ & $\begin{array}{c}\text { Rata- } \\
\text { rata }\end{array}$ \\
\hline 1 & $\begin{array}{l}\text { Pertanian, } \\
\text { Kehutanan, dan } \\
\text { Perikanan }\end{array}$ & 0,52 & 0,54 & 0,55 & 0,56 & 0,56 & 0,59 & 0,60 & 0,57 \\
\hline 2 & $\begin{array}{l}\text { Pertambangan dan } \\
\text { Penggalian }\end{array}$ & 2,22 & 2,4 & 2,21 & 2,31 & 2,25 & 2,01 & 1,95 & 2,19 \\
\hline 3 & Industri Pengolahan & 1,6 & 1,66 & 1,68 & 1,66 & 1,64 & 1,63 & 1,63 & 1,65 \\
\hline 4 & $\begin{array}{l}\text { Pengadaan Listrik } \\
\text { dan Gas }\end{array}$ & 1,24 & 1,53 & 1,59 & 1,59 & 1,6 & 1,71 & 1,75 & 1,63 \\
\hline 5 & $\begin{array}{l}\text { Pengadaan Air, } \\
\text { Pengelolaan } \\
\text { Sampah, Limbah } \\
\text { dan Daur Ulang }\end{array}$ & 0,63 & 0,61 & 0,63 & 0,63 & 0,62 & 0,62 & 0,62 & 0,62 \\
\hline 6 & \begin{tabular}{l} 
Konstruksi \\
\hline 7
\end{tabular} & 0,9 & 0,88 & 0,88 & 0,9 & 0,97 & 0,98 & 1,00 & 0,94 \\
\hline 8 & $\begin{array}{l}\text { Perdagangan Besar } \\
\text { Reparasi Mobil dan } \\
\text { Sepeda Motor }\end{array}$ & 0,64 & 0,62 & 0,64 & 0,64 & 0,65 & 0,67 & 0,67 & 0,65 \\
\hline $\begin{array}{l}\text { Pransportasi dan } \\
\text { Pergudangan }\end{array}$ & 0,8 & 0,76 & 0,75 & 0,74 & 0,72 & 0,73 & 0,72 & 0,74 \\
\hline
\end{tabular}

143 OECONOMICUS Journal of Economics 
Sektor Unggulan Dan Pergeseran Sektoral

\begin{tabular}{|c|c|c|c|c|c|c|c|c|c|}
\hline & Makan Minum & & & & & & & & \\
\hline 10 & $\begin{array}{l}\text { Informasi dan } \\
\text { Komunikasi }\end{array}$ & 0,8 & 0,75 & 0,75 & 0,75 & 0,74 & 0,75 & 0,76 & 0,75 \\
\hline 11 & $\begin{array}{l}\text { Jasa Keuangan dan } \\
\text { Asuransi }\end{array}$ & 0,46 & 0,43 & 0,42 & 0,41 & 0,41 & 0,41 & 0,42 & 0,42 \\
\hline 12 & Real Estat & 0,78 & 0,73 & 0,73 & 0,71 & 0,71 & 0,74 & 0,75 & 0,73 \\
\hline 13 & Jasa Perusahaan & 0,34 & 0,34 & 0,34 & 0,34 & 0,34 & 0,34 & 0,35 & 0,34 \\
\hline 14 & $\begin{array}{l}\text { Administrasi } \\
\text { Pemerintahan, } \\
\text { Pertahanan dan } \\
\text { Jaminan Sosial Wajib }\end{array}$ & 0,51 & 0,51 & 0,52 & 0,51 & 0,51 & 0,52 & 0,53 & 0,52 \\
\hline 15 & Jasa Pendidikan & 0,33 & 0,31 & 0,31 & 0,31 & 0,31 & 0,31 & 0,32 & 0,31 \\
\hline 16 & $\begin{array}{l}\text { Jasa Kesehatan dan } \\
\text { Kegiatan Sosial }\end{array}$ & 0,66 & 0,58 & 0,59 & 0,57 & 0,57 & 0,57 & 0,58 & 0,58 \\
\hline 17 & Jasa lainnya & 0,19 & 0,19 & 0,2 & 0,19 & 0,19 & 0,19 & 0,19 & 0,19 \\
\hline
\end{tabular}

Sumber: PDRB Menurut Provinsi Jawa Timur Menurut Lapangan Usaha 2011-2017, diolah

Hasil Perhitungan DLQ Kabupaten Gresik

\begin{tabular}{|l|l|l|l|l|l|l|l|l|}
\hline No & Sektor & $\mathbf{2 0 1 2}$ & $\mathbf{2 0 1 3}$ & $\mathbf{2 0 1 4}$ & $\mathbf{2 0 1 5}$ & $\mathbf{2 0 1 6}$ & $\mathbf{2 0 1 7}$ & $\begin{array}{l}\text { Rata- } \\
\text { rata }\end{array}$ \\
\hline 1 & $\begin{array}{l}\text { Pertanian, Kehutanan, dan } \\
\text { Perikanan }\end{array}$ & 0.90 & 1.00 & 0.97 & 1.01 & 1.09 & 1.04 & 1.002 \\
\hline 2 & Pertambangan dan Penggalian & 1.36 & 0.75 & 1.48 & 1.06 & 0.65 & 0.96 & 1.043 \\
\hline 3 & Industri Pengolahan & 0.99 & 1.08 & 0.97 & 1.00 & 0.99 & 0.98 & 1.001 \\
\hline 4 & Pengadaan Listrik dan Gas & 1.79 & 0.93 & 0.80 & 0.83 & 1.04 & 0.86 & 1.042 \\
\hline 5 & $\begin{array}{l}\text { Pengadaan Air, Pengelolaan } \\
\text { Sampah, Limbah dan Daur Ulang }\end{array}$ & 0.73 & 1.21 & 1.09 & 1.00 & 1.01 & 1.05 & 1.012 \\
\hline 6 & Konstruksi Eceran; & 0.70 & 0.94 & 1.07 & 1.44 & 0.96 & 1.04 & 1.024 \\
\hline 7 & $\begin{array}{l}\text { Perdagangan Besar dan Enan } \\
\text { Reparasi Mobil dan Sepeda Motor }\end{array}$ & 0.71 & 1.01 & 1.08 & 1.07 & 1.16 & 1.06 & 1.015 \\
\hline 8 & Transportasi dan Pergudangan \\
\hline 9 & $\begin{array}{l}\text { Penyediaan Akomodasi dan } \\
\text { Makan Minum }\end{array}$ & 0.72 & 1.11 & 1.03 & 1.05 & 1.09 & 1.07 & 1.012 \\
\hline 10 & Informasi dan Komunikasi & 0.64 & 1.07 & 1.07 & 1.09 & 1.13 & 1.16 & 1.025 \\
\hline 11 & Jasa Keuangan dan Asuransi & 0.69 & 1.01 & 1.01 & 1.12 & 1.13 & 1.16 & 1.020 \\
\hline 12 & Real Estat & 0.65 & 1.01 & 1.02 & 1.06 & 1.29 & 1.12 & 1.025 \\
\hline
\end{tabular}

Sumber: PDRB Menurut Provinsi Jawa Timur Menurut Lapangan Usaha 2011-2017, diolah

Tabel di atas memaparkan hasil perhitungan DLQ Kabupaten Gresik pada tahun 2011-2017. Nilaii rata-rata DLQ Kabupaten Gresik pada kurun waktu tersebut dari setiap sektornya hampir sama. 
Akan tetapi jika dilihat pada setiap tahunnya, nilai DLQ Kabupaten Gresik mengalami fluktuatif meskipun perubahannya tidak begitu besar.

Klasifikasi Sektor Berdasarkan Nilai DLQ dan LQ Kabupaten Gresik

\begin{tabular}{|c|c|c|}
\hline KRITERIA & $\mathrm{LQ}>1$ & $\mathrm{LQ}<1$ \\
\hline \multirow[t]{14}{*}{ DLQ $>1$} & $\begin{array}{l}\text { Pertambangan dan } \\
\text { Penggalian }\end{array}$ & Pertanian, Kehutanan, dan Perikanan \\
\hline & Industri Pengolahan & $\begin{array}{l}\text { Pengadaan Air, Pengelolaan Sampah, Limbah } \\
\text { dan Daur Ulang }\end{array}$ \\
\hline & $\begin{array}{l}\text { Pengadaan Listrik dan } \\
\text { Gas }\end{array}$ & Konstruksi \\
\hline & & $\begin{array}{l}\text { Perdagangan Besar dan Eceran; Reparasi Mobil } \\
\text { dan Sepeda Motor }\end{array}$ \\
\hline & & Transportasi dan Pergudangan \\
\hline & & Penyediaan Akomodasi dan Makan Minum \\
\hline & & Informasi dan Komunikasi \\
\hline & & Jasa Keuangan dan Asuransi \\
\hline & & Real Estat \\
\hline & & Jasa Perusahaan \\
\hline & & $\begin{array}{l}\text { Administrasi Pemerintahan, Pertahanan dan } \\
\text { Jaminan Sosial Wajib }\end{array}$ \\
\hline & & Jasa Pendidikan \\
\hline & & Jasa Kesehatan dan Kegiatan Sosial \\
\hline & & Jasa lainnya \\
\hline DLQ $<1$ & SEKTOR PROSPEKTIF & SEKTOR TERTINGGAL \\
\hline
\end{tabular}

Sumber: BPS Jatim, diolah

Tabel di atas menglasifikasikan seluruh sektor berdasarkan nilai dari LQ dan DLQ. Pada tabel tersebut menunjukkan bahwa yang termasuk dalam kelompok sektor unggulan ada tiga sektor yaitu sektor pertambangan dan penggalian, sektor industri pengolahan, dan sektor pengadaan listrik dan gas. 
Ketiga sektor unggulan ini memiliki potensi pada saat ini dan masih akan tetap berpotensi pada waktu kedepan. Sedangkan sektor-sektor lainnya masuk kedalam kelompok sektor andalan yang pada saat ini belum dikatakan sebagai sektor unggulan,akan tetapi sektor andalan ini berpotensi menjadi sektor unggulan pada waktu kedepan. Berdasarkan nilai perhitungan LQ dan DLQ pada setiap sektor, tidak ada yang masuk dalam kelompok sektor prospektif dan sektor andalan. Jadi Kabupaten Gresik hanya memiliki dua kelompok sektor yaitu sektor unggulan dan sektor andalan.

\section{Pergeseran Sektoral Di Kabupaten Gresik 2011-2017}

Pergeseran sektoral yang terjadi di suatu daerah dianalisis dengan perhitungan Shift Share, adapun untuk Kabupaten Gresik selama kurun waktu 2011-2017 adalah sebagai berikut:

\begin{tabular}{|c|l|c|c|c|}
\hline No & \multicolumn{1}{|c|}{ Sektor } & PRij & PPij & PPWij \\
\hline & & 2079.125 & 1161.938 & 761.413 \\
\hline & Pertanian, Kehutanan, dan Perikanan & & & - \\
\hline & Pertambangan dan Penggalian & 3708.557 & -606.144 & 1516.814 \\
\hline 3 & Industri Pengolahan & 14041.339 & 1336.557 & 125.219 \\
\hline 4 & Pengadaan Listrik dan Gas & 160.086 & -151.801 & 137.315 \\
\hline 5 & $\begin{array}{l}\text { Pengadaan Air, Pengelolaan Sampah, Limbah dan Daur } \\
\text { Ulang }\end{array}$ & 19.421 & -4.638 & -1.383 \\
\hline 6 & Konstruksi & 2315.739 & 277.312 & 736.049 \\
\hline 7 & $\begin{array}{l}\text { Perdagangan Besar dan Eceran; Reparasi Mobil dan } \\
\text { Sepeda Motor }\end{array}$ & 3204.163 & 699.831 & 411.207 \\
\hline 8 & Transportasi dan Pergudangan & 622.031 & 210.096 & -237.327 \\
\hline 9 & Penyediaan Akomodasi dan Makan Minum & 304.403 & 144.363 & -22.666 \\
\hline 10 & Informasi dan Komunikasi & 1094.057 & 754.578 & -256.135 \\
\hline
\end{tabular}


Abdul Hakim

\begin{tabular}{|c|l|c|c|c|}
11 & Jasa Keuangan dan Asuransi & 288.219 & 163.473 & -105.592 \\
\hline 12 & Real Estat & 362.666 & 67.392 & -60.958 \\
\hline 13 & Jasa Perusahaan & 76.575 & 2.517 & 0.409 \\
\hline 14 & $\begin{array}{l}\text { Administrasi Pemerintahan, Pertahanan dan Jaminan } \\
\text { Sosial Wajib }\end{array}$ & 387.174 & -203.028 & 18.354 \\
\hline 15 & Jasa Pendidikan & 233.146 & 49.564 & -25.010 \\
\hline 16 & Jasa Kesehatan dan Kegiatan Sosial & 102.053 & 74.824 & -51.777 \\
\hline 17 & Jasa lainnya & 86.100 & -19.755 & -0.345 \\
\hline & \multicolumn{2}{|l}{29084.854} & 0.000 & 1127.954 \\
\hline
\end{tabular}

Sumber: BPS Jatim, diolah

Tabel di atas menunjukkan bahwa seluruh sektor di Kabupaten Gresik memiliki nilai PRij positif. Hal ini menjelaskan bahwa seluruh sektor di Kabupaten Gresik mengalami pertumbuhan lebih cepat dari pada pertumbuhan seluruh sektor yang ada di Jawa Timur.

Sedangkan untuk nilai PPij, Kabupaten Gresik memiliki tujuh sektor yang memiliki nilai PPij negatif dan sepuluh sektor yang memiliki nilai positif. Sektor-sektor yang memiliki nilai negatif di antaranya yaitu (1) Sektor pertanian, kehutanan, dan perikanan, (2) Sektor pertambangan dan penggalian, (3) Sektor industri pengolahan, (4) Sektor pengadaan listrik dan gas, (5) Sektor Pengadaan air, pengelolaan sampah, limbah dan daur ulang, (6) Sektor administrasi pemerintahan, (7) Jasa lainnya. Ketujuh sektor ini merupakan sektor yang lamban dan pertumbuhannya karena lebih rendah dari pada pertumbuhan ekonomi Jawa Timur.

Selain itu Kabupaten Gresik memiliki sepuluh sektor yang memiliki nilai PPij positif. Sektor-sektor yang memiliki nilai PPij positif diantaranya yaitu (1) Sektor konstruksi, (2) Sektor perdagangan besar dan eceran, (3) Sektor transportasi dan pergudangan, (4) Sektor penyediaan akomodasi dan makan minum, (5) Sektor informasi dan komunikasi, (6) Sektor jasa keuangan dan asuransi, (7) Sektor real estat, (8) Sektor jasa perusahaan, (9) Sektor jasa pendidikan, (10) Sektor jasa kesehatan dan kegiatan sosial. Sepuluh sektor tersebut merupakan 
sektor-sektor maju dan memiliki pertumbuhan yang lebih tinggi dari pada pertumbuhan ekonomi Jawa Timur.

Kabupaten Gresik juga memiliki dua belas sektor yang memiliki nilai PPWij negatif. Dua belas sektor tersebut diantaranya yaitu (1) Sektor pertambangan dan penggalian, (2) Sektor Pengadaan air, pengelolaan sampah, limbah dan daur ulang, (3) Sektor transportasi dan pergudangan, (4) Sektor penyediaan akomodasi dan makan minum, (5) Sektor informasi dan komunikasi, (6) Sektor jasa keuangan dan asuransi, (7) Sektor real estat, (8) Sektor jasa perusahaan, (9) Sektor administrasi pemerintahan, (10) Sektor jasa pendidikan, (11) Sektor jasa kesehatan dan kegiatan sosial, (12) Sektor jasa lainnya. Dua belas sektor tersebut memiliki daya saing rendah.

Sementara itu, Kabupaten Gresik hanya memiliki lima sekor yang memiliki nilai PPWij positif. Lima sektor tersebut yaitu (1) Sektor pertanian, kehutanan, dan perikanan, (2) Sektor indistri pengolahan, (3) Sektor pengadaan listrik dan gas, (4) Sektor konstruksi, (5) Sektor perdagangan besar dan eceran. Lima sektor ini merupakan sektor yang memiliki daya saing yang kuat karena produk dari lima sektor tersebut memiliki kemampuan ekspor (basis) ke daerah lain. Demikian itu merupakan kondisi pergeseran sektoral yang terjadi di Kabupaten Gresik selama 2011-2017.

\section{Pembangunan Ekonomi Regional Di Kabupaten Gresik 2011-2017}

Pengembangan sektor unggulan yang dimiliki daerah tercermin pada visi dan misi daerah yang tertuang di dalam rencana pembangunan jagka panjang daerah (RPJPD) dan rencana jangka menengah daerah (RPJMD). Selain itu, anggaran pendapatan dan belanja Daerah (APBD) harus mencerminkan program-program dan tujuan-tujuan pembangunan. Karena suatu renana akan bersifat operasionil apabila anggarannya tersedia.

Dukungan Pemerintah Kabupaten Gresik dalam pengembangan potensi ekonomi lokalnya tercermin dalam prioritas program dalam dokumen RPJPD tahun 2005-2025 dan dokumen RPJMD tahun 20112015, yakni sektor yang diprioritaskan dalam pembangunan adalah sektor industri pengolahan; perdagangan, hotel, dan restoran; serta sektor pertanian.

Pengembangan sektor industri dinilai sudah sangat tepat karena sektor industri berdasarkan hasil LQ mendapatkan nilai 1,99 yang 
berarti > 1 menandakan bahwa sektor tersebut merupakan sektor unggulan dan masuk kategori sektor unggulan yang mampu bersaing dengan sektor yang sama di daerah lain. Namun, pengembangan di sektor industri hanya mendapatkan alokasi anggaran rata-rata cukup sedikit, yakni senilai Rp. 451.329.666,67. Sedangkan, prioritas program di sektor lainnya seperti perdagangan, hotel, dan restoran dinilai kurang tepat karena sektor perdagangan, hotel, dan restoran secara rata-rata mendapat nilai $\mathrm{LQ}<1$, menandakan bahwa sektor tersebut bukan sektor basis (unggulan). Tetapi, faktor lokasional Kabupaten Gresik yang dekat dengan pelabuhan, yakni pelabuhan perak dan pelabuhan Gresik sendiri, serta dekat dengan akses pasar, selain itu terpenuhinya sarana prasarana seperti jalan tol, kondisi jalan dan jembatan yang cukup baik membuat sektor ini cukup kompetitif meskipun bukan sektor unggulan, sehingga produk yang dihasilkan mampu bersaing dengan daerah lain.

Sektor pertanian khususnya sub sektor perikanan dan kelautan adalah sektor selanjutnya yang menapatkan prioritas program. Alasan utama Kabupaten mengembangkan sektor ini adalah karena sepertiga wilayah Gresik merupakan perairan sehingga potensial untuk dikembangkan perikanan. Padahal jika dilihat dari hasil analisis LQ sektor ini bukan sektor unggulan karena secara rata-rata, sektor pertanian mendapatkan hasil LQ 0,59. Selain itu, tidak mampu bersaing dengan daerah lain. Sehingga prioritas di bidang ini tidak akan menguntungkan pemerintah, namun disisi lain pembangunan dibidang pertanian juga sangat diperlukan untuk menyeimbangkan industrialisasi agar tidak terjadi konversi lahan besar-besaran, konversi wilayah industri harus berdasarkan RTRW, RDTRK, Program Lahan Pertanian yang Dipertahankan. Sektor pertanian mendapatkan dukungan anggaran yang paling besar diantara sektor lainnya yakni Rp. 13.950.155.097,00.

Sedangkan, sektor listrik, gas, dan air bersih serta sektor pertambangan dan penggalian juga tidak mendapatkan prioritas program di RPJPD, namun sektor-sektor tersebut mendapatkan perhatian pada RPJMD. Padahal, jika dilihat berdasarkan nilai LQ sektor listrik, gas dan air bersih termasuk sektor basis (unggulan) dengan nilai LQ sebesar 1,42; begitu pula dengan sektor pertambangan dan penggalian yang mendapat nilai LQ 1,36; Selain itu, kedua sektor ini merupakan sektor yang mampu bersaing dengan sektor yang sama 
di daerah lain. Jadi, dukungan program pemerintah pada sektor tersebut sudah tepat, namun dukungan dalam bidang anggaran dirasa kurang tepat karena pada sektor ini hanya mendapatkan anggaran sebesar Rp. 129.221.631,67. Pengembangan potensi unggulan ini diamanatkan melalui penyelenggaraan pemerintahan daerah agar mempecepat terwujudnya daya saing daerah, dimana hal tersebut salah satunya dapat dilaksanakan melalui pembangunan ekonomi daerah melalui pengembangan potensi daerahnya.

Berdasarkan dokumen RPJPD dan RPJMD Prioritas program pemerintah Kabupaten Gresik adalah mengembangkan sektor industri pengolahan; sektor perdagangan, hotel, dan restoran; serta sektor pertanian. Dari ketiga sektor tersebut yang cukup mencerminkan pengembangan potensi ekonomi unggulan berdasarkan analisis Location Quoteint (LQ) dan Shift Share (SS) adalah pengembangan di sektor indusri pengolahan. Jika pemerintah fokus pada pengembangan semua sektor unggulan maka, kemungkinan besar pemerintah dapat meningkatkan daya saing daerahnya pula. Syafar (2004) dalam Sumihardjo (2008, h.9) menjelaskan bahwa daya saing daerah berkaitan erat dengan kemampuan ekonomi daerah dalam hal ini terkait dengan pemanfaatan potensi daerah untuk menghasilkan dan memasarkan produk atau jasa yang dibutuhkan oleh pasar secara berkesinambungan.

\section{Penutup}

Dari hasil analisis LQ, didapatkan bahwa ada tiga sektor unggulan di Kabupaten Gresik yang memberikan kontribusi besar bagi PDRB Gresik dan pertumbuhan sektor lain. Ketiga sektor unggulan tersebut adalah sektor pertambangan dan penggalian, sektor industri pengolahan, sektor pengadaan listrik dan gas. Dari hasil analisis DLQ di Kabupaten Gresik selama tahun 2011 sampai 2017, menunjukkan bahwa terdapat dua klasifikasi sektor di Kabupaten Gresik, yaitu sektor unggulan dan sektor andalan. Sektor unggulan yaitu sektor yang berpotensi pada saat ini dan akan tetap berpotensi pada waktu kedepan. Sedangkan sektor andalan yaitu sektor yang belum berpotensi pada saat ini tetapi memiliki kemungkinan yang besar menjadi sektor unggulan pada waktu yang akan datang. Sektor-sektor andalan di 
Kabuaten Gresik meliputi seluruh sektor di luar sektor unggulannya. Sektor unggulan dan sektor andalan ini perlu dikembangkan karena sektor ini berpotensi memberikan kontribusi besar bagi pendapatan Kabupaten Gresik.

Hasil analisis shift share terhadap seluruh sektor yang ada di Kabupaten Gresik mengalami pertumbuhan yang lebih tinggi dari pada pertumbuhan total seluruh sektor yang ada di Jawa Timur. Kabupaten Gresik memilki sepuluh sektor-sektor maju yaitu (1) Sektor konstruksi, (2) Sektor perdagangan besar dan eceran, (3) Sektor transportasi dan pergudangan, (4) Sektor penyediaan akomodasi dan makan minum, (5) Sektor informasi dan komunikasi, (6) Sektor jasa keuangan dan asuransi, (7) Sektor real estat, (8) Sektor jasa perusahaan, (9) Sektor jasa pendidikan, (10) Sektor jasa kesehatan dan kegiatan sosial. Sektorsektor maju ini memiliki pertumbuhan yang lebih tinggi dari pada pertumbuhan ekonomi di Jawa Timur. Kabupaten Gresik juga memiliki lima sektor yang memiliki daya saing yang tinggi yaitu (1) Sektor pertanian, kehutanan, dan perikanan, (2) Sektor indistri pengolahan, (3) Sektor pengadaan listrik dan gas, (4) Sektor konstruksi, (5) Sektor perdagangan besar dan eceran.

Dalam perspektif ekonomi regional atau wilayah, pengembangan sektor unggulan dan pergerseran sektoral di Kabupaten Gresik memiliki peranan penting dalam mendorong pertumbuhan ekonomi, peningkatan kesempatan kerja, dan penurunan tingkat kemiskinan. Ketiga sektor unggulan yang ada di Kabupaten Gresik (pertambangan dan penggalian, industri pengolahan, sektor pengadaan listrik dan gas) dapat dikembangkan dengan strategi-strategi dalam perencanaan pengembangan wilayah. Untuk sektor andalan di Kabupaten Gresik dapat dikembangkan menjadi sektor unggulan jika pemerintah daerah mampu memberikan strategi pembangunan yang tepat misalnya memberikan porsi anggaran yang lebih besar. 


\section{Daftar Referensi}

Arsyad, L. 1999. Pengantar Perencanaan dan Pembangunan Ekonomi Daerah (1sted.). Yogyakarta: BPFE.

Arsyad, Lincolin, 2004. Ekonomi Pembangunan. Yogyakarta: STIE YKPN. Arsyad, Lincolin. "Pengantar Perencanaan Ekonomi Daerah (edisi kedua)". Badan Pusat Statistik (BPS), 2017. Gresik dalam Angka 2010-2017.

----, 2017. PDRB Kabupaten Gresik Menurut Pengeluaran 2010-2017

-----, 2017. PDRB Menurut Kabupaten Kota Menurut Lapangan Usaha 2010-2017

----, 2017. PDRB Menurut Provinsi Jawa Timur Menurut Lapangan Usaha 2010-2017

Daryanto, Arief \& Hafizrianda. 2010. Model-model Kuantitatif untuk

Perencanaan Pembangunan Ekonomi Daerah: Konsep dan Aplikasi. IPB Press: Bogor.

Djojohadikusumo, Sumitro. 1994. Dasar Teori Ekonomi Pertumbuhan dan Ekonomi Pembangunan . Jakarta:LP3ES.

Emilia dan Imelia. "Modul Ekonomi Regional" Jurusan Ilmu Ekonomi FakultasEkonomi Universitas Jambi. 2006

Jhingan, M.L., 2004, Ekonomi Pembangunan dan Perencanaan. Rajawali Press: Jakarta.

Kuncoro, Mudrajad. 2014. Otonomi Daerah Menuju Era Pembangunan Daerah Edisi 3. Penerbit Erlangga: Jakarta.

Rustiadi, E, Saefulhakim S, dan Panuju D.R. 2009. Perencanaan dan Pengembangan Wilayah. Jakarta: Crestpent Press dan Yayasan Obor Indonesia.

Sjafrizal, 2008. Ekonomi Regional, Teori dan Aplikasi, Baduose Media, Cetakan Pertama, Padang.

Sugiyono, Metode PenelitianKombinasi (Mixed Methods), Alfabeta: Bandung Cetakan : Ke - 8. :2016.

Tarigan, Robinson. "Perencanaan Pembangunan Wilayah (edisi revisi)". Jakarta:Press. 2009

Tarigan, Robinson. 2012. Ekonomi Regional Teori dan Aplikasi, Bumi Aksara: Jakarta.

Todaro, Michael P \& Stephen C. Smith. 2003. Pembangunan Ekonomi di Dunia Ketiga.Jilid 1. Edisi Delapan. Terjemahan oleh Haris Munandar. 2003. Penerbit Erlangga: Jakarta.

Zakaria, Junaiddin. "Pengantar Teori Ekonomi Makro". Jakarta: Gaung PersadaYogyakarta: BPFE. 2002. 